\title{
ANATOMICAL EVALUATION OF THE PEDICLE OF THE AXIS THROUGH COMPUTERIZED TOMOGRAPHY IN ADULTS
}

\author{
AVALIAÇÃO ANATÔMICA DO PEDÍCULO DO ÁXIS ATRAVÉS DE TOMOGRAFIA \\ COMPUTTADORIZADA EM ADULTOS
}

\section{EVALUACIÓN ANATÓMICA DEL PEDÍCULO DEL AXIS A TRAVÉS DE LA TOMOGRAFÍA COMPUTARIZADA EN ADULTOS}

\author{
Jean Almeida de Souza, ${ }^{1}$ Tiago Youssef Ammar, ${ }^{1}$ Guilherme Baldissera Damiani, ${ }^{1}$ Álvaro Diego Heredia Suarez, ${ }^{1}$ Leandro de Freitas Spinelli, ${ }^{2,3}$ \\ Jean Marcel Dambrós ${ }^{1}$ \\ 1. Instituto de Ortopedia e Traumatologia de Passo Fundo, Hospital São Vicente de Paulo, Spinal Surgery, Passo Fundo, RS, Brazil. \\ 2. Department of Orthopedics and Traumatology. Complexo Hospitalar da Santa Casa de Porto Alegre, RS, Brasil. \\ 3. Universidade de Passo Fundo, Faculdade de Engenharia e Arquitetura, Bioengineering, Biomechanics, and Biomaterials Laboratory, Passo Fundo, RS, Brazil.
}

\begin{abstract}
Objectives: The topography of the high cervical spine involves several traumatic, degenerative, and rheumatologic pathologies. With the evolution of surgical techniques and synthesis materials available for use in such region, an optimization of the anatomical understanding of this area is required. Methods: Therefore, this study evaluated 62 computed tomographies of the high cervical spine in an adult population, aiming at the study of the anatomical parameters of the axis pedicle. The measures analyzed in this observational study were pedicle length at axial section, pedicle length at sagittal section, pedicle thickness at axial section and interpedicular angulation. Results: Computed tomography is a necessary exam for the programming of C2 pedicle screws and is useful for determining the anatomical changes and evaluating the length of the screws that will be used. Furthermore, no statistically significant difference was observed in the length, angulation, and diameter of the pedicles of the axis in relation to sex or age. Conclusion: Regarding sex and age, no statistically significant difference on length, angulation, and pedicle diameter occur. There is an urgent need for computed tomography for surgical planning. Level of Evidence II; Transversal Diagnostic Studies - Investigation of a Diagnosis Test.
\end{abstract}

Keywords: Axis, Cervical Vertebra; Parameters; Computed Tomography.

\section{RESUMO}

Objetivos: A topografia da coluna cenvical alta envolve diversas patologias de cunho traumático, degenerativo e reumatológico. Com a evolução de técnicas cirúrgicas e de materiais de síntese disponíveis para uso em tal região, é necessária uma otimização do entendimento anatômico desta área. Métodos: Assim, este estudo avaliou 62 tomografias computadorizadas da coluna cervical alta na população adulta, visando o estudo dos parâmetros anatômicos do pedículo do Áxis. Comprimento do pedículo no corte axial, comprimento do pedículo no corte sagital, espessura do pedículo no corte axial e angulação interpedicular foram as medidas analisadas neste estudo observacional. Resultados: A tomografia computadorizada mostra-se como um exame necessário para a programação da passagem de parafusos pediculares de C2, sendo útil para determinar as alterações anatômicas e avaliar o comprimento dos parafusos que irão ser utilizados. Também, não foram observadas diferenças estatisticamente significantes no comprimento, angulação e diâmetro dos pedículos do áxis em relação ao sexo. Conclusão: Não foram observadas diferenças estatisticamente significantes no comprimento, na angulação e no diâmetro dos pedículos. Urge a necessidade da Tomografia Computadorizada para o planejamento cirúrgico. Nível de Evidência II; Estudos Transversais de diagnósticos - Investigação de um exame para diagnóstico.

Descritores: Vértebra Cervical Áxis; Parâmetros; Tomografia Computadorizada.

\section{RESUMEN}

Objetivos: La topografía de la columna cervical alta involucra diversas patologías de origen traumático, degenerativo y reumatológico. Con la evolución de técnicas quirúrgicas y de materiales de síntesis disponibles para uso en tal región, es necesaria una optimización del entendimiento anatómico de esta área. Métodos: Así, este estudio evaluó 62 tomografías computarizadas de columna cervical alta en una población adulta, visando el estudio de los parámetros anatómicos del pedículo de axis. Las medidas analizadas en este estudio observacional fueron la longitud del pedículo en corte axial, la longitud del pedículo en corte sagital, el espesor del pedículo en corte axial y la angulación interpedicular. Resultados: La tomografía computarizada se muestra como un examen necesario para la programación del paso de tornillos pediculares de C2, siendo útil para determinar los cambios anatómicos y evaluar la longitud de los tornillos que se van a utilizar. Además, no se observó diferencias estadísticamente significativas en la longitud, angulación y diámetro de los pedículos del áxis en relación al sexo. Conclusión: En relación al sexo y edad no ocurren diferencias estadísticamente significativas en la longitud, la angulación y el diámetro de los pedículos. Urge la necesidad de la tomografía computarizada para la planificación quirúrgica. Nivel de Evidencia II; Estudios transversales de diagnóstico - Investigación de un examen para diagnóstico.

Descriptores: Vértebra Cervical Axis; Parámetros; Tomografía Computarizada.

This study was conducted at the Spinal Surgery Service of the Hospital São Vicente de Paulo and the Instituto de Ortopedia e Traumatologia, both in Passo Fundo/RS. Correspondence: "IvânioTagliari". Hospital São Vicente de Paulo/ Rua Uruguai, 2050. Passo Fundo/RS. Contato: (54) 3045- 9975 E-mail: pesquisa2@hsvp.com.br 


\section{INTRODUCTION}

The occiput, atlas, and axis make up the upper cervical region. This region is responsible for approximately half of the cervical rotation movement $(\mathrm{C} 1-\mathrm{C} 2)$ and half of the cervical flexion movement (occiput-C1). Pathologies such as Down syndrome, rheumatoid arthritis, fractures, luxations, and ligamentous lesions are the main indications for surgical intervention in this area. ${ }^{1,2}$

Posterior cervical spine instrumentation systems have evolved from wire sutures to fixation of the lateral masses, and posterior to cervical pedicle screws. However, this type of fixation is especially challenging to spine surgeons due to the proximity of the pedicle to the spinal cord, nerve roots, and vertebral arteries. ${ }^{3,4}$

In 2001, Harms and Melcher reported the advent of posterior atlantoaxial fracture stabilization by inserting screws in the lateral mass of $\mathrm{C} 1$ and in the pedicle of C2. Subsequently, several studies used this approach and showed that posterior approach pedicle screw fixation is a safe and effective method for treating atlantoaxial fractures, achieving up to $100 \%$ fusion rates without any injury to the vertebral artery or spinal cord. ${ }^{5-9}$

Although it is a safe and effective method, it is not clear whether the diameter and length of the screws available on the market are the most suitable for the overall Brazilian population. ${ }^{9}$ As the suitability of implants is critical to the success of the technique, this study aimed to evaluate this issue.

\section{METHODS}

This retrospective observational study was conducted using a sample comprised of patients treated at the Hospital São Vicente de Paulo (HSVP) and the Instituto de Ortopedia e Traumatologia (IOT), both in Passo Fundo/RS, who underwent computed tomography of the cervical spine for which axial, coronal, and sagittal sections were identified in all the examinations. The study was conducted during the period from January 2010 to August 2016 and was approved by the Institutional Review Board of the Universidade de Passo Fundo as opinion number 1.613.071.

Patients with inconclusive or poor quality imaging exams, high cervical spinal fractures, presence of synthesis material in the cervical spine, younger than or equal to 18 years of age, or with degenerative changes in the cervical spine resulting from the rheumatologic process were excluded from the analyses.

The anatomical region was evaluated in patients who underwent computed tomography. The researchers did not have any contact with the patients, who were not identified, so no ICFs were required. Therefore, there was no risk of discomfort to the patients. The following parameters were analyzed and quantified: the interpedicular angle, the sagittal and axial lengths of the pedicle, and the thickness of the pedicle in the axial section. (Figure 1)

The data obtained were first plotted in an electronic Excel spreadsheet and then transferred to SPSS version 19 for statistical analysis. Initially, descriptive analysis of the values obtained was performed evaluating the mean, standard deviation (SD), median, minimum, and maximum values. Then the Kolmogorov- Smirnov test was performed to evaluate the normal distribution of each parameter. An investigation of the influence of sex and age ( $<60$ and $>=60$ years of age) on the measurements was performed using the Student's t-test. The association between the measurements was also conducted through Pearson's correlation analysis. All the tests conducted were two-tailed and considered to be significant when $\mathrm{p}<0.05$

\section{RESULTS}

The analysis was conducted from tomographies of 62 patients (24 men and 38 women) with a mean age of $43.9 \pm 16.3$ years (minimum $=18$, maximum $=87$ ). Table 1 shows the results of the main parameters evaluated. The values obtained for each parameter investigated had normal distribution. (Figure 2)

An additional analysis was conducted to evaluate a possible correlation between the parameters investigated. As can be seen in

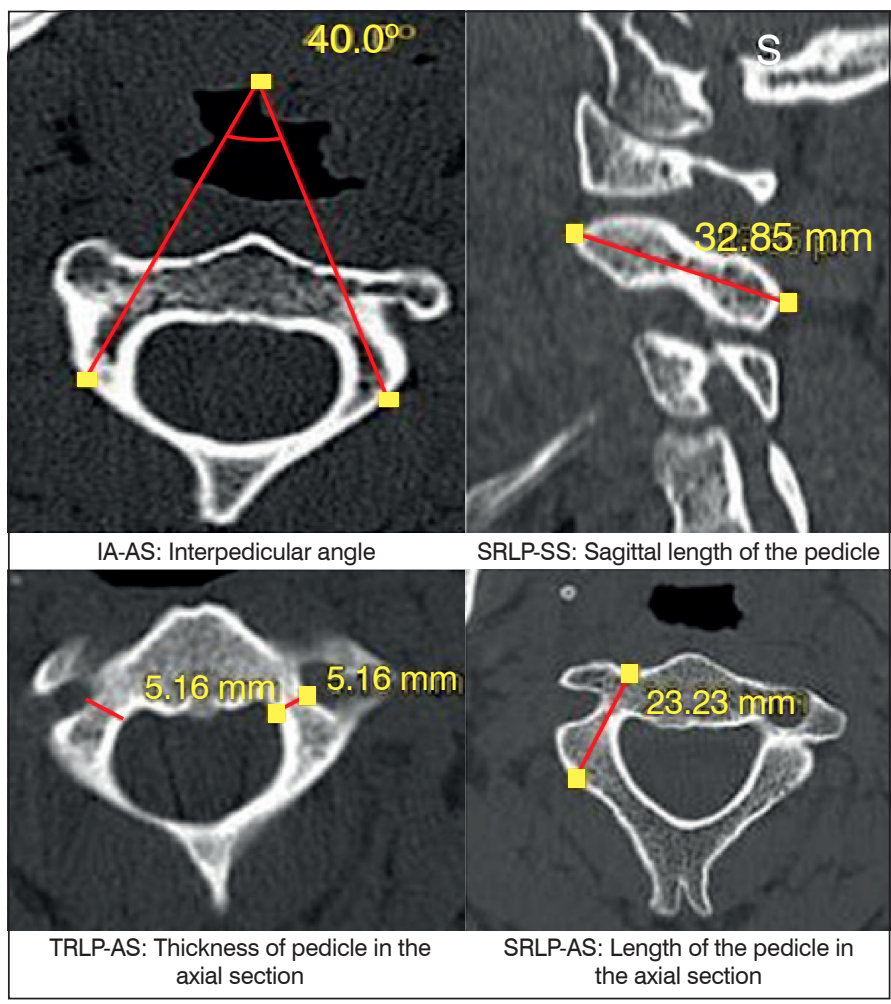

Figure 1. Computed tomography image of the spine (C2/Axis) showing the parameters investigated.

Table 1. Quantitative parameters observed in computed tomography of the cervical spine (C2/Axis)

\begin{tabular}{c|c|c|c}
\hline Parameters & Mean \pm sd & Median & Minimum-Maximum \\
\hline SRLP-SS $(\mathrm{mm})$ & $32.7 \pm 2.7$ & 32.5 & $23.7-38.8$ \\
\hline SLRP-AS $(\mathrm{mm})$ & $22.42 \pm 2.2$ & 22.5 & $17.5-27.1$ \\
\hline IA-AS $\left(^{\circ}\right)$ & $50.3 \pm 6.9$ & 49.0 & $40-68$ \\
\hline TRLP-AS $(\mathrm{mm})$ & $5.54 \pm 0.5$ & 5.5 & $4.0-6.8$ \\
\hline
\end{tabular}

sd = standard deviation; SRLP-SS = size of the right and left pedicles, sagittal section; SRLP-AS = size of the right and left pedicles, axial section; IA-AS = interpedicular angle - axial section; TRLP-AS $=$ thickness of the right and left pedicles - axial section.

Table 2, the measurements of SRLP-SS were moderate and positively associated with the SRLP-AS measurements. That is, the greater the SRLP-SS values, the greater the values of SRLP-AS. The other significant correlation observed occurred between the values of IA-AS and TRLP-AS. However, although the correlation was significant, it was low $\left(r^{2}<0.30\right)$ and negative, i.e., the greater the value of IA-AS, the lower the value of the TRLP-AS measurement.

Two additional analyses were conducted to evaluate the potential influence of sex and age ( $<60$ and $\geq 60$ years) on the measurements. However, the results showed that none of these variables had significant influence on the measurements evaluated.

\section{DISCUSSION}

This study evaluated tomographic measurements of the high cervical spine in Brazilian patients, encountering no significant statistical diferences values regarding sex or age. This evaluation was relevant because an ever-increasing number of surgical procedures are being performed for the treatment of pathology of the upper cervical spine. Several surgical techniques involve the insertion of screws into the pedicles of C2/Axis. However, due to the presence of anatomical changes in the vertebrae, the placement of these screws cannot be accomplished in up to $20 \%$ of cases.

In our study, the pedicles of the axis of an adult Brazilian population were evaluated by means of computed tomography in an attempt to compare the results and establish an anatomical norm for the size and thickness of both the pedicle and the 


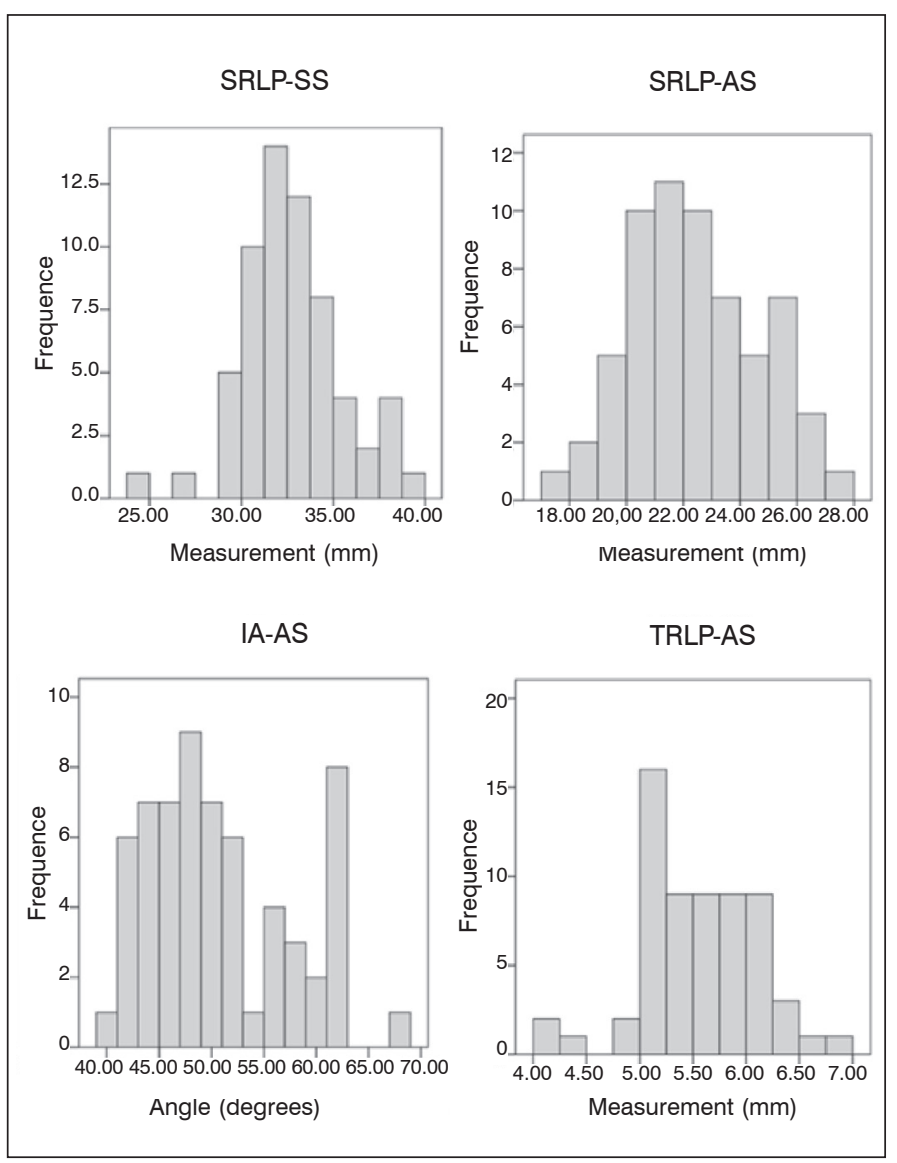

Figure 2. Distribution of the values of the measurements analyzed from computed tomographies of the spine (C2/Axis).
Table 2. Analysis of the Pearson correlation between the computed tomography measurements of the spine (C2/Axis).

\begin{tabular}{c|c|c|c|c|c}
\hline & & SRLP-SS & SRLP-AS & IA-AS & TRLP-AS \\
\hline SRLP-SS & $\mathrm{r}^{2}$ & 1 & $0.424^{*}$ & 0.98 & 0.14 \\
\hline & $\mathrm{p}$ & & 0.001 & 0.448 & 0.915 \\
\hline SRLP-AS & $\mathrm{r}^{2}$ & & 1 & 0.167 & -0.12 \\
\hline & $\mathrm{p}$ & & & 0.195 & 0.924 \\
\hline IA-AS & $\mathrm{r}^{2}$ & & & 1 & -2.69 \\
\hline & $\mathrm{p}$ & & & & 0.035 \\
\hline
\end{tabular}

$\mathrm{R}^{2}=$ value of the correlation; $\mathrm{p}=$ significance of the analysis.

interpedicular angle. Screws with a diameter of $3.5 \mathrm{~mm}$ and length ranging from 12 to $30 \mathrm{~mm}$ are commonly found on the market. The adequacy of implant measurements is fundamental to the success of the technique.

Vizurraga et al. conducted an anatomical study of the C2 pedicles in axial cuts of 89 computed tomographies. This study found a mean thickness of the axis pedicle of $5.5 \mathrm{~mm}( \pm 1.45 \mathrm{~mm})$. Thus, as in our case series, we did not find any patient with a mean right and left side pedicle thickness less than $4 \mathrm{~mm}$, a measurement considered safe for the passage of a $3.5 \mathrm{~mm}$ screw.

The limitation of our study is the small size of the patient sample.

\section{CONCLUSION}

We did not observe any statistical difference in the length, the angulation, and the diameter of the pedicles of the axis in relation to sex or age. Computed tomography proved to be a necessary examination in the planning of the insertion of pedicle screws in C2 and useful in determining any anatomical changes and assessing the length of the screws to be used.

All authors declare no potential conflict of interest related to this article.

CONTRIBUTION OF THE AUTHORS: Each author made significant individual contributions to this manuscript. TYA (0000-0003-3105-4872)* and JAS $(0000-0002-1226-4578)^{\star}$ were the main contributors to the writing of the manuscript. GBD $(0000-0001-9261-3207)^{\star}$, ADHS $(0000-0001-6561-9654)^{\star}$, and JMD (0000-0002-2871-5660)* evaluated the tomography examinations. JAS and LFS (0000-0001-8125-7104)* evaluated the statistical data. TYA and JAS conducted the bibliographical research, reviewed the manuscript, and contributed to the intellectual concept of the study. ${ }^{*}$ ORCID (Open Researcher and Contributor ID).

\section{REFERENCES}

1. Wright NM, Lauryssen C. Vertebral artery injury in C1-2 transarticular screw fixation: results of a survey of the AANS/CNS section on disorders of the spine and peripheral nerves. American Association of Neurological Surgeons/Congress of Neurological Surgeons. J Neurosurg.1998;88(4):634-40.

2. Jeanneret B, Magerl F. Primary posterior fusion C1/2 in odontoid fractures: indications, technique, and results of transarticular screw fixation. J Spinal Disord. 1992;5(4):464-75.

3. Ebraheim NA, Fow J, Xu R, Yeasting RA. The location of the pedicle and pars interarticularis in the axis. Spine (PhilaPa 1976). 2001:26(4):E34-7.

4. Ebraheim N, Rollins JR Jr, Xu R, Jackson WT. Anatomic consideration of the C2 pedicle screw placement. Spine (Phila Pa 1976). 1996;21(6):691-5.

5. Harms J, Melcher RP. Posterior C1-C2 fusion with polyaxial screw and rod fixation. Spine. $2001 ; 26(22): 2467-71$

6. Nitising A, Jetjumnong C, Tisavipat N, Nantaaree S. Posterior C1-C2 fusion using C1 lateral mass and C2 pars screw with rod fixation: techniques and outcomes. J Med Assoc Thai. 2011:94(7):794-800

7. Ma C, Wu J, Zhao M, Dai W, Wu D, Wang Z, et al. Treatment of upper cervical spine instability with posterior fusion plus atlantoaxial pedicle screw. Cell BiochemBiophys. 2011:69(3):693-7.

8. Aryan HE, Newman CB, Nottmeier EW, Acosta FL Jr, Wang VY, Ames CP. Stabilization of the atlantoaxial complex via C-1 lateral mass and C-2 pedicle screw fixation in a multicenter clinical experience in 102 patients: modification of the Harms and Goel techniques. J Neurosurg Spine. 2008:8(3):222-9.

9. Vizurraga DE, Rhee JM, Borden TC, Mansour AS. "Inline" axial reconstructed CT scans provide a significantly larger assessment of C2 pedicle diameter for srew placement compared with "standard" axial scans: implications for surgical planning. Clin Spine Surg. 2016;30(8):E1039-45. 